\title{
Expression and differential regulation of human TERRA at several chromosome ends
}

\author{
MARIANNA FERETZAKI, ${ }^{1}$ PATRICIA RENCK NUNES, ${ }^{1}$ and JOACHIM LINGNER \\ Swiss Institute for Experimental Cancer Research (ISREC), School of Life Sciences, Ecole Polytechnique Fédérale de Lausanne (EPFL), \\ 1015 Lausanne, Switzerland
}

\begin{abstract}
The telomeric long noncoding RNA TERRA has been implicated in regulating telomere maintenance by telomerase and homologous recombination, and in influencing telomeric protein composition during the cell cycle and the telomeric DNA damage response. TERRA transcription starts at subtelomeric regions resembling the CpG islands of eukaryotic genes extending toward chromosome ends. TERRA contains chromosome-specific subtelomeric sequences at its $5^{\prime}$ end and long tracts of UUAGGG-repeats toward the $3^{\prime}$ end. Conflicting studies have been published as to whether TERRA is expressed from one or several chromosome ends. Here, we quantify TERRA species by RT-qPCR in normal and several cancerous human cell lines. By using chromosome-specific subtelomeric DNA primers, we demonstrate that TERRA is expressed from a large number of telomeres. Deficiency in DNA methyltransferases leads to TERRA up-regulation only at the subset of chromosome ends that contain CpG-island sequences, revealing differential regulation of TERRA promoters by DNA methylation. However, independently of the differences in TERRA expression, short telomeres were uniformly present in a DNA methyltransferase deficient cell line, indicating that telomere length was not dictated by TERRA expression in cis. Bioinformatic analyses indicated the presence of a large number of putative transcription factors binding sites at TERRA promoters, and we identified a subset of them that repress TERRA expression. Altogether, our study confirms that TERRA corresponds to a large gene family transcribed from multiple chromosome ends where we identified two types of TERRA promoters, only one of which is regulated by DNA methylation.
\end{abstract}

Keywords: TERRA; long noncoding RNA; telomeres; telomere length

\section{INTRODUCTION}

Telomeres form complex nucleoprotein structures located at the ends of linear chromosomes. Functional telomeres enable genome stability by repressing DNA damage signaling and preventing inappropriate recruitment of DNA repair enzymes (Lazzerini-Denchi and Sfeir 2016; de Lange 2018). Telomeric proteins promote efficient replication fork progression through the telomere (Miller et al. 2006; Sfeir et al. 2009). In germ, stem, and cancer cells, telomeric proteins also recruit the telomerase reverse transcriptase to counteract telomere shortening (Schmidt and Cech 2015). Although telomeres have features of heterochromatin (Tardat and Déjardin 2018), they are transcribed into the long noncoding RNA termed TERRA (Azzalin and Lingner 2015). TERRA is broadly expressed in eukaryotes being transcribed by RNA polymerase II from subtelomeric sequences into the telomeric tract (Nergadze et al. 2009; Porro et al. 2014a). A subset of TERRA promoters contains

\footnotetext{
${ }^{1}$ These authors contributed equally to this work.

Corresponding author: joachim.lingner@epfl.ch

Article is online at http://www.rnajournal.org/cgi/doi/10.1261/rna. 072322.119.
}

CpG islands (Nergadze et al. 2009). The TERRA sequence has remained highly conserved throughout eukaryotes because of the location and orientation of TERRA transcription and the rather strong conservation of telomeric DNA sequences that generally consist of $T$ and $G$ rich repeats in the strand containing the $3^{\prime}$ end of chromosomes.

TERRA has been implicated in regulating telomere maintenance by telomerase and by homologous recombination (Schoeftner and Blasco 2008; Redon et al. 2010; Pfeiffer and Lingner 2012; Cusanelli et al. 2013; Arora et al. 2014; Moravec et al. 2016; Graf et al. 2017). TERRA can bind to telomerase repressing its activity in vitro (Schoeftner and Blasco 2008; Redon et al. 2010). In vivo, TERRA has been proposed to guide Saccharomyces cerevisiae telomerase to chromosome ends that are particularly short to promote their preferential elongation (Cusanelli et al. 2013). Telomerase promoting functions have also

(C) 2019 Feretzaki et al. This article is distributed exclusively by the RNA Society for the first 12 months after the full-issue publication date (see http://rnajournal.cshlp.org/site/misc/terms.xhtml). After 12 months, it is available under a Creative Commons License (Attribution-NonCommercial 4.0 International), as described at http:// creativecommons.org/licenses/by-nc/4.0/. 
been proposed for TERRA in Schizosaccharomyces pombe (Moravec et al. 2016). On the other hand, in S. cerevisiae, overexpression of TERRA from one chromosome end led to telomere shortening in cis, which, however, was mediated by increased activity of the end processing enzyme exonuclease 1 at the chromosome end from which TERRA was expressed (Pfeiffer and Lingner 2012). In addition, high levels of TERRA and very short telomeres have been observed in a subset of patients suffering from the ICF syndrome (Immunodeficiency, Centromere instability, Facial anomalies), in which the DNA methyltransferase enzyme DNTM3b is defective (Yehezkel et al. 2008). It has been proposed that the telomere shortening in ICF patients is linked to telomeric DNA/RNA hybrid structures or R-loops stimulated by high TERRA levels, which can interfere with the semiconservative replication of the telomeric repeats (Sagie et al. 2017).

TERRA can stimulate homologous recombination at telomeres. In telomerase-negative cancer cell lines, which rely on the ALT pathway (Pickett and Reddel 2015), up-regulation of TERRA leads to increased R-loop formation at chromosome ends, which promotes telomere maintenance through homologous recombination (Arora et al. 2014). In S. cerevisiae, short telomeres express higher levels of TERRA and the resulting R-loops promote homology-directed repair and maintenance of critically short telomeres (Graf et al. 2017). In both cases, precise regulation of R-loop formation is essential to allow telomeric HR to occur while not severely compromising semiconservative telomere replication. RNaseH enzymes, which degrade the RNA moiety in DNA/RNA hybrid structures, and the THO complex, which promotes RNA release from chromatin during transcription, cooperate to remove excessive amounts of hybrids to ensure telomere integrity (Pfeiffer and Lingner 2012; Balk et al. 2013; Arora et al. 2014; Graf et al. 2017).

TERRA has also been implicated in regulating the telomeric heterochromatin structure. Upon telomeric chromatin damage mediated by depletion of TRF2, TERRA is up-regulated, reinforcing the interaction between the telomere end processing nuclease MRE11 and its activating lysine demethylase LSD1 (Porro et al. 2014b; Hirschi et al. 2016). TERRA may also promote histone H3 trimethylation (Deng et al. 2009). The SUV39H1 H3K9 histone methyltransferase, which promotes accumulation of $\mathrm{H} 3 \mathrm{~K} 9 \mathrm{me} 3$ at damaged telomeres and end-to-end fusions, regulates and associates with TERRA (Arnoult et al. 2012; Porro et al. 2014a). Finally, the H3K27 histone trimethylase PRC2 can bind TERRA, possibly promoting this histone modification at chromosome ends (Wang et al. 2017).

Whereas TERRA has been reported to be expressed in a variety of eukaryotes from several chromosome ends, conflicting reports exist for its expression in mice and men. For mouse TERRA, the Blasco laboratory reported that TERRA stems mostly from chromosome 18 (López de Silanes et al.
2014) whereas others detected its expression at multiple chromosome ends (Mazzolini et al. 2018; Liu et al. 2019). For human cells, the Blasco laboratory reported that TERRA stems mainly from chromosome end 20q (Montero et al. 2016) whereas other groups (Nergadze et al. 2009; Arnoult et al. 2012; Deng et al. 2012; Porro et al. 2014a) reported TERRA expression from a variety of chromosome ends. In this paper, we clarify this issue quantifying TERRA molecules stemming from different chromosome ends in a variety of human cell types representing normal cells, telomerase-positive cancer cells, and cells maintaining telomeres by the ALT pathway. We demonstrate that TERRA is generated from a large gene family, being expressed in variable amounts at a large set of chromosome ends. Our study also identifies regulators of TERRA expression and different types of TERRA promoters, only a subset of which is regulated by DNA methyltransferases.

\section{RESULTS}

\section{Quantification of TERRA stemming from different chromosome ends}

We sought to determine the origins and relative numbers of TERRA molecules from various chromosome ends in a variety of human cell lines using real-time RT-PCR quantification (Feretzaki and Lingner 2017). For this, total RNA was extracted from normal telomerase-negative human lung fibroblasts (HLF), the telomerase-positive cervical carcinoma cell line HeLa, the osteosarcoma-derived telomerase-negative ALT cell line U2OS, and the telomerase-positive colorectal carcinoma cell line HCT116 and its derivative carrying a homozygous truncated version of DNA methyltransferase 1 (DNMT1) and a homozygous deletion of DNMT3B (DNMT1 $\Delta$ exons3-5/4exons3-5; DNMT3B ${ }^{-1-}$ ), referred to as HCT116-DKO (Rhee et al. 2002; Egger et al. 2006). RNA was reverse-transcribed with DNA oligonucleotides that were complementary to the UUAGGG-repeats present at the $3^{\prime}$ end of TERRA molecules. Upon reverse transcription, the subtelomeric portions of the resulting cDNAs were amplified by quantitative PCR using oligonucleotide primers that were designed to be specific for individual chromosome ends and as close as possible to the terminal TTAGGG repeats (50-300 bp from the telomeric tract). The identity of the PCR products was confirmed by DNA fragment size and DNA sequence analyses. Initially, we sought to determine the number of TERRA species per $\mu \mathrm{g}$ of RNA by creating plasmid-based standard curves and real-time RT-PCR absolute quantification. The subtelomeric DNA for each TERRA species was subcloned into pcDNA4 vectors and confirmed by sequence analysis. The standard curves for each TERRA species were obtained using 2 to $2 \times 10^{8} \mathrm{~mol}-$ ecules of plasmid per reaction (Supplemental Fig. S1A). 
The amplification efficiencies were close to $100 \%$, with the slopes of standard curves ranging from -3.013 to -3.226 $\left(R^{2}>0.99\right)$. Amplification of the TERRA samples and standard dilutions was performed at the same time. The $C_{t}$ values obtained from TERRA samples were compared with their corresponding standard curves to calculate the number of TERRA molecules per $\mu \mathrm{g}$ of total RNA. The reverse transcription reaction was assumed to be $100 \%$ efficient (Fig. 1). Based on this analysis, we demonstrate that TERRA is expressed from numerous chromosome ends and that the relative expression values vary among the different cell types analyzed. Significantly, the results also indicated that 20q TERRA is not the main TERRA species in U2OS or any of the human cell lines tested in contrast to what was previously proposed (Montero et al. 2016).

To eliminate possible confounding effects due to variations in the efficiency of reverse transcription and to determine the number of TERRA molecules per cell, we quantified TERRA species from 10q, 15q, and 20q telomeres using standard curves obtained from serial dilutions of an in vitro transcribed TERRA (Table 1; Supplemental Fig. S1B). The in vitro transcribed TERRA was gel purified,

A
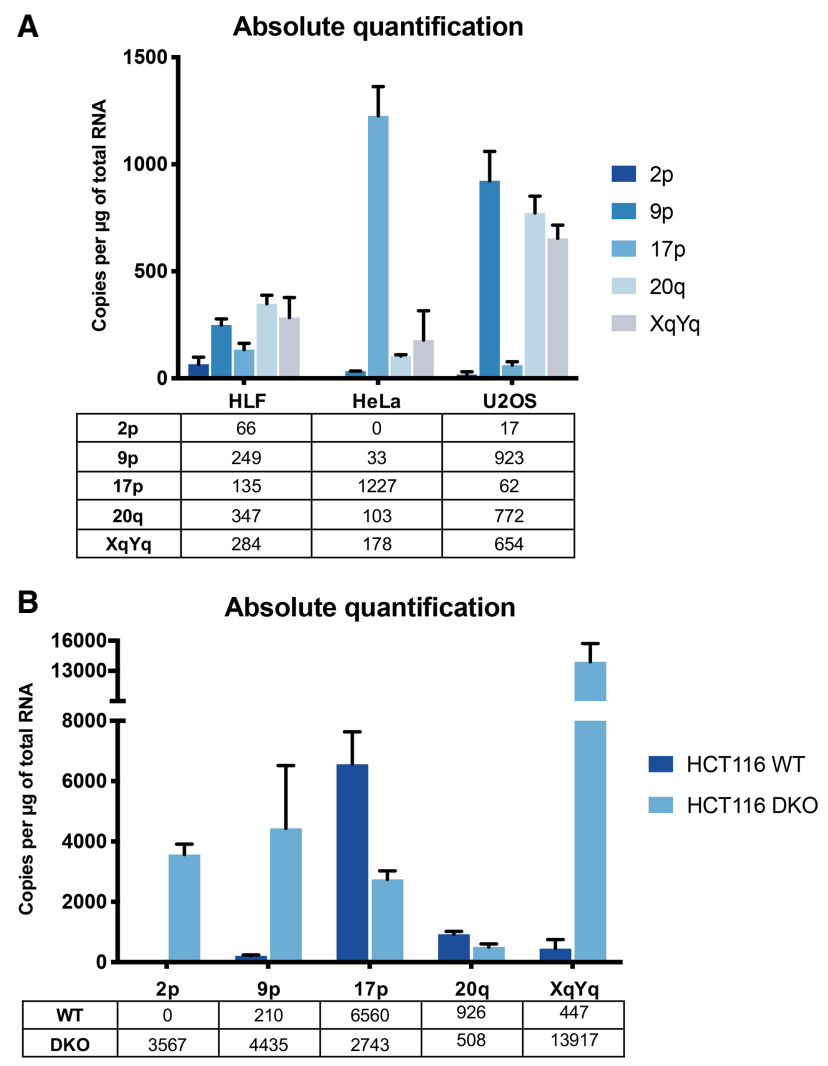

FIGURE 1. Absolute quantification of TERRA in human cell lines. (A) HLF, HeLa and U2OS. (B) HCT116 and HCT116 DKO. Quantification was performed by RT-qPCR using standard curves prepared with plasmid standards containing subtelomeric sequences of the indicated telomeres. RT efficiency was assumed to be $100 \%$ efficient.
TABLE 1. Average number of TERRA molecules per cel

\begin{tabular}{lccc}
\hline Cell line & $10 q$ & $15 q$ & $20 q$ \\
\hline U2OS & $164 \pm 41$ & $63 \pm 9$ & $4 \pm 1$ \\
HLF & $0.8 \pm 0.1$ & $8 \pm 1$ & $1 \pm 1$ \\
HeLa & $2 \pm 1$ & $5 \pm 1$ & $1 \pm 1$ \\
HCT116 WT & $2 \pm 1$ & $22 \pm 4$ & $8 \pm 2$ \\
HCT116 DKO & $954 \pm 65$ & $298 \pm 12$ & $4 \pm 1$ \\
\hline
\end{tabular}

reverse-transcribed, subcloned, and subjected to DNA sequencing analysis to verify its sequence and size. Tenfold serial dilutions of each RNA standard and cell-derived RNA were reverse-transcribed and the desired TERRA species were amplified with specific oligonucleotides, as mentioned above. This analysis confirmed that $20 q$ TERRA is not the main TERRA species in none of the cell lines. Furthermore, it allowed an estimation of average TERRA molecule number per cell, which varied for the analyzed TERRA species between a few molecules to several hundred in DNA methyltransferase deficient HCT116 cells (Table 1). Overall, the results indicated that different TERRA species vary in quantity among each other and that their relative expression levels are not constant in different cell lines. This analysis does not consider the known cell cycle regulation of TERRA nor possible cell-to-cell variations. Of note, HeLa cells are polyploid with a variable number of chromosomes depending on the isolate (Landry et al. 2013; Frattini et al. 2015). U2OS cells are triploid for chromosomes 15q, 10q, and 20q (Ozaki et al. 2003; Janssen and Medema 2013). HCT116, HCT116DKO, and HLF are diploid (Knutsen et al. 2010; Passerini et al. 2016).

\section{Defects in DNA methyltransferases lead to TERRA up-regulation in dependency on the presence of CpG islands}

Even though HCT116 DKO cells are known to overexpress TERRA similar to ICF patients, the extent of the increase had not been determined for individual TERRA species. The analyses in Figure 1 and Table 1 already revealed that only a subset of TERRA species is up-regulated in HCT116-DKO cells in comparison to the parental cell line. To further elucidate the effects of DNA methyltransferase deficiency in the HCT116-DKO, we extended this analysis comparing the relative expression levels of TERRA from 14 different chromosome ends (Fig. 2A). Ten of these $(1 q, 2 p, 9 p, 10 q, 12 q, 13 q, 15 q, 16 p, 18 q$, XqYq) showed strong up-regulation of TERRA in HCT116-DKO cells whereas 7p, 17p, 20q, and XpYp did not reveal TERRA up-regulation upon loss of DNA methyltransferases. To understand the mechanism behind this 
A

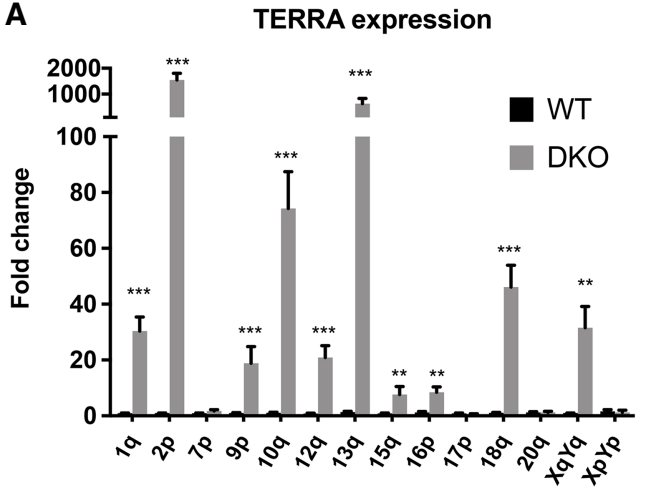

B

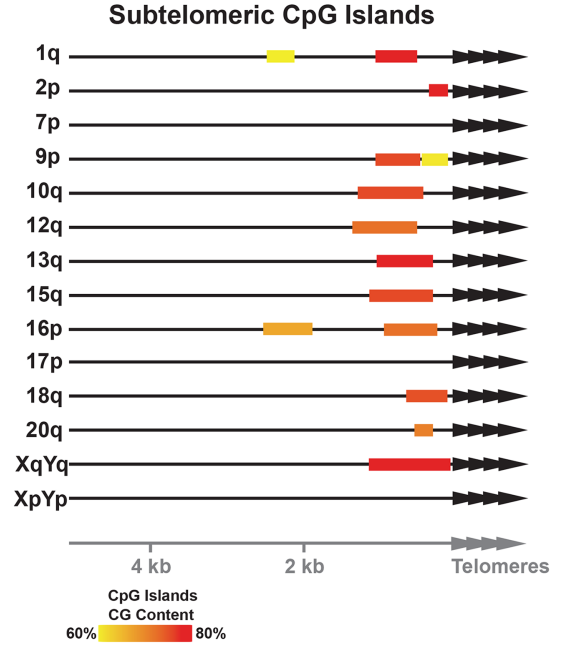

FIGURE 2. Relative TERRA expression levels in HCT116 WT and DKO cells. (A) Relative quantification of TERRA expression in HCT116 WT and DKO cells. WT TERRA levels were adjusted to 1. (**) $P<0.01,\left(^{* * *}\right) P<0.001, n=3$. (B) Representation of position and CG content of subtelomeric $\mathrm{CpG}$ islands at the indicated chromosome ends.

phenotype, we analyzed the composition of the first $15 \mathrm{~kb}$ of subtelomeric DNA sequence for the presence of CpG islands potentially involved in promoting TERRA transcription when undermethylated. Any sequence longer than 200 bp with more than $60 \%$ GC content was considered a CpG island. As seen in Figure 2B, roughly $75 \%$ of the analyzed chromosome ends contained CpG islands, in accordance with previously published data (Koskas et al. 2017). Very strikingly, the up-regulation of TERRA correlated with the presence of $\mathrm{CpG}$ islands in the subtelomeric TERRA promoters (Fig. 2B). The 20q TERRA contains a very short $\mathrm{CpG}$ island with low CG content, which can explain why we did not observe high levels of this TERRA species in HCT116-DKO. Overall, our data reveal the existence of two types of TERRA promoters that either do contain or do not contain $\mathrm{CPG}$ island promoters. Only the latter type is regulated by DNA methyltransferases, which can methylate the $\mathrm{CpG}$ island containing promoters limiting TERRA expression.

\section{Telomere shortening in a DNA methyltransferase deficient cell line at all chromosome ends independently of TERRA expression in cis}

ICF-syndrome derived cell lines as well as HCT116-DKO cells express high levels of TERRA and carry very short telomeres (Yehezkel et al. 2008; Farnung et al. 2012). It has been proposed that the short telomere phenotype is linked to the elevated TERRA levels. Our data revealed that TERRA up-regulation in HCT116-DKO cells is limited only to a subset of telomeres. Thus, we wanted to investigate the impact of high TERRA levels on each corresponding telomere and assess the correlation between the short telomere phenotype and the CpG island-derived up-regulated TERRA. To measure the length of individual telomeres we used single telomere length analysis (STELA) in HCT116-DKO. STELA consists of a long-range small pool PCR with forward primers specific to the telomere of interest (Baird et al. 2003). The telomeric DNA 5' ends are ligated to an adaptor primer (telorette) that is complementary to the telomeric $3^{\prime}$ overhang. Small pool PCR is performed with a primer complementary to the adaptor (TelTail primer) and a subtelomeric specific primer. We designed and validated by cloning and sequencing specific primers for $9 p, 17 p$, and $20 q$ STELAs. The $15 q$ STELA primers were described previously (Farnung et al. 2012). In Figure 3, we measured by STELA the telomere lengths in HCT116 and HCT116-DKO cells for two telomeres that overexpressed TERRA (9p and 15q) and two telomeres with similar TERRA expression (17p and 20q) between the two cell lines. Independently of changes in relative TERRA expression, all the analyzed telomeres were between $1.5 \mathrm{~kb}$ and $2.1 \mathrm{~kb}$ shorter in HCT116DKO versus wild type. This indicates that if TERRA is responsible for the short telomere phenotype in these cells, the effect is not restricted to the telomeres that transcribe large quantities of TERRA.

\section{ZNF148, ZFX, EGR1, and PLAG1 repress TERRA expression}

The regulation of TERRA expression appears to be complex as it responds in addition to DNA methylation, to cell cycle progression, the telomeric DNA damage response, and telomere length (Porro et al. 2010, 2014b; Arnoult et al. 2012). A couple of transcription factors have been identified to regulate TERRA expression including CTCF, ATRX, NRF1, HSF1, Snail, and p53 (Deng et al. 2012; Lovejoy et al. 2012; Episkopou et al. 2014; Eid et al. 2015; Flynn et al. 2015; Diman et al. 2016; Tutton et al. 2016; Koskas et al. 2017; Mazzolini et al. 2018). In a previous study, we identified the transcription start sites of multiple TERRA molecules as far as 5-10 kb upstream of the TTAGGG repeats. A bioinformatics analysis of the region upstream of these sites revealed a plethora of cis- 
A
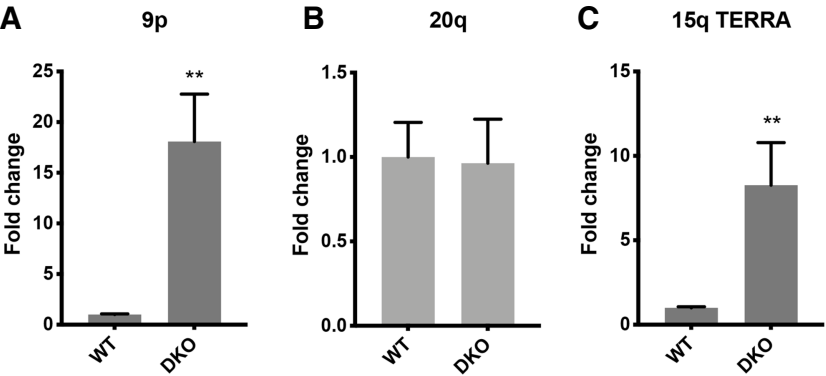

D

E 気 9p STELA 20q STELA 害 $\mathbf{F}$

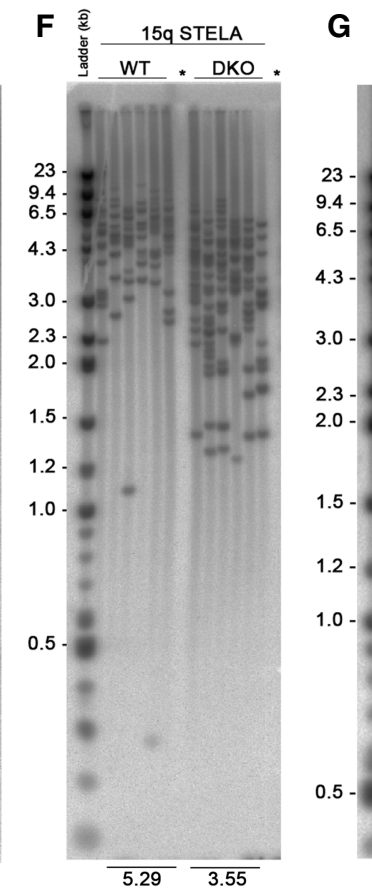

G
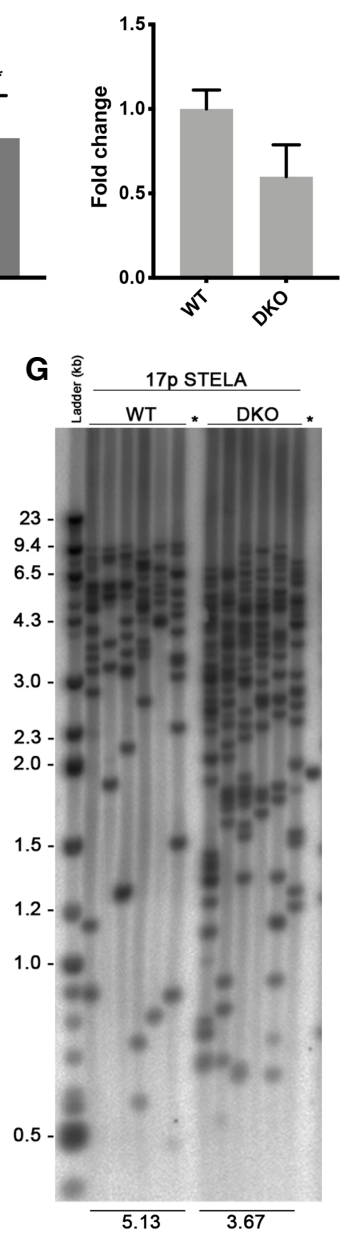

H
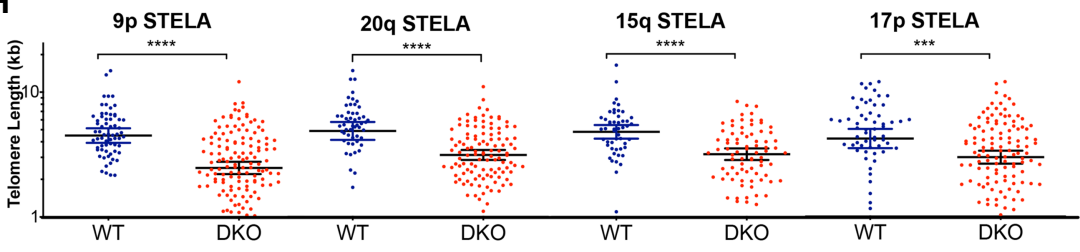

FIGURE 3. TERRA expression and telomere length at individual chromosome ends do not correlate in HCT116 DKO cells. 9p (A), 20q (B), 15q (C), and 17p (D) TERRA expression was measured by RT-qPCR in HCT116 WT and DKO cells. TERRA levels were normalized to GAPDH. $N=3$. STELA was performed to measure telomere length of 9p, 20q $(E), 15 q$ $(F)$, and $17 p(G)$ telomeres. Each lane corresponds to an independent small pool PCR done with genomic DNA of the indicated cell line. Negative controls were done without telorette ligation (lanes marked with an asterisk). (H) Scattered plot (geometric mean $\pm 95 \%$ confidence interval) representing the same results as in $E, F$, and $G$. Each band is represented by one dot. $\left(^{* *}\right) P<0.01,\left({ }^{* *}\right) P<0.001,\left({ }^{* * *}\right) P<0.0001$.

regulatory elements and transcription factors that may control TERRA expression. We expanded the bioinformatic analyses to cover the vicinity of putative TERRA transcription start sites near the immediate predicted start sites to the $2 \mathrm{~kb}$ region preceding the canonical 5'-TTAGGG-3' telomeric repeats (Porro et al. 2014a). Very frequently identified binding motifs present at a large number of 17p TERRA

chromosome ends are listed in Table 2. We then ordered several siRNAs for depleting the identified transcription factors. We transfected HeLa cells with the siRNAs and measured TERRA by RT-qPCR $48 \mathrm{~h}$ post-transfection. Depletion of CTCF reduced TERRA expression, as expected for its known roles in promoting TERRA transcription, validating our approach (Deng et al. 2012). Previous studies have shown that ATRX inactivation leads to an increase in global TERRA levels possibly due to de-regulation of the cell cycle-depend transcription of TERRA in HeLa and U2OS (Lovejoy et al. 2012; Flynn et al. 2015). On the other hand, two studies demonstrated that removal of ATRX in glioma cell lines and immortalized fibroblasts led to a decrease of TERRA transcription (Episkopou et al. 2014; Eid et al. 2015). We found that ATRX depletion caused up-regulation of TERRA at several chromosome ends in HeLa cells consistent with its role as a repressor of TERRA expression (Fig. 4B). In addition, depletion of transcription factors ZNF148, ZFX, EGR1, or PLAG1 was achieved, and depletion of all four factors resulted in TERRA up-regulation at several or all analyzed chromosome ends (Fig. 4). Therefore, these factors all act as negative regulators of TERRA. The high number of putative binding sites in the subtelomeric region suggests that their effects on TERRA expression may be direct; however, indirect effects cannot be excluded. ZNF148 is part of the Kruppel family of zinc finger DNA binding proteins and can function as an activator or repressor (Passantino et al. 1998). ZFX contains 13 zinc finger domains and is required for the self-renewal of hematopoietic stem cells (GalanCaridad et al. 2007; Harel et al. 2012). Early growth response 1 (EGR1) activates genes involved in cell growth and angiogenesis, and its expression increases upon hTERT overexpression (Park et al. 2016). The PLAG1 zinc finger protein is consistently rearranged in salivary gland pleomorphic adenoma, and its up-regulation promotes the development of hepatoblastoma (Aström et al. 1999; Zatkova et al. 2004). 
TABLE 2. Motifs of transcriptional regulatory elements found in the different subtelomeres by FIMO

\begin{tabular}{|c|c|c|c|c|c|c|c|c|c|c|c|}
\hline \multirow[b]{2}{*}{ TF } & \multicolumn{6}{|c|}{ CpG-positive chromosome ends } & \multicolumn{4}{|c|}{ CpG-negative chromosome ends } & \multirow[b]{2}{*}{ Sum } \\
\hline & $9 p$ & $10 q$ & $15 q$ & $16 p$ & $19 p$ & $\mathrm{XqYq}$ & $7 p$ & $17 p$ & $20 q$ & XpYp & \\
\hline CTCF & 25 & 8 & 19 & 16 & 24 & 29 & 15 & 8 & 18 & 8 & 170 \\
\hline PLAG1 & 11 & 8 & 16 & 12 & 8 & 13 & 18 & 1 & 19 & 60 & 166 \\
\hline EGR1 & 8 & 8 & 4 & 7 & 9 & 7 & 6 & 8 & 4 & 2 & 63 \\
\hline SP1 & 110 & 49 & 98 & 119 & 136 & 165 & 86 & 58 & 89 & 289 & 1199 \\
\hline ZFX & 79 & 56 & 69 & 56 & 59 & 68 & 56 & 8 & 36 & 56 & 543 \\
\hline ZNF148 & 32 & 45 & 19 & 26 & 35 & 24 & 26 & 10 & 44 & 48 & 309 \\
\hline EWSR1 & 5 & 4 & 3 & 8 & 6 & 8 & 2 & 4 & 6 & 2 & 48 \\
\hline AP2A1 & 8 & 8 & 7 & 3 & 1 & 7 & 6 & 8 & 2 & 4 & 54 \\
\hline SMAD4 & 3 & 7 & 8 & 9 & 6 & 2 & 2 & 4 & 5 & 10 & 56 \\
\hline CACYBP & 28 & 29 & 12 & 8 & 14 & 12 & 19 & 16 & 6 & 9 & 153 \\
\hline KLF15 & 8 & 4 & 3 & 14 & 5 & 15 & 5 & 6 & 22 & 22 & 104 \\
\hline PEBP1 & 4 & 6 & 3 & 1 & 2 & 7 & 6 & 6 & 1 & 9 & 45 \\
\hline MAZ & 32 & 25 & 29 & 35 & 29 & 19 & 28 & 19 & 22 & 90 & 328 \\
\hline SP2 & 66 & 98 & 48 & 56 & 49 & 69 & 59 & 35 & 36 & 189 & 705 \\
\hline ZNF263 & 35 & 25 & 19 & 20 & 18 & 33 & 19 & 36 & 7 & 36 & 248 \\
\hline ZNF281 & 145 & 89 & 116 & 143 & 151 & 143 & 189 & 36 & 80 & 357 & 1449 \\
\hline
\end{tabular}

\section{DISCUSSION}

In this paper, we developed PCR primers and quantified TERRA stemming from several chromosome ends with unprecedented accuracy. Our data indicate that the number of TERRA molecules per cell stemming from different chromosome ends varies from less than 10 to several hundred in cancer-derived ALT-cells or HCT116-derived DNA methyltransferase deficient cells. The quantity of individual TERRA molecules stemming from different chromosome ends also varies substantially within a given cell type. This variability is larger than the variability of telomeric DNA repeats at different chromosome ends. We interpret this finding as to reflect a function of TERRA in modulating the association of chromatin and DNA modifying enzymes rather than providing an important structural role at telomeres to recruit in a constitutive manner telomere binding proteins. The individual state of each telomere dictates its corresponding TERRA transcription, which can be highly variable not only among cell types but among telomeres of the same cell. At individual chromosome ends, TERRA expression may respond to local alterations in telomere length and protein composition in order to trigger a telomere-specific response. For example, TERRA expression increases at short telomeres promoting homologous recombination in cells that lack telomerase (Arora et al. 2014; Graf et al. 2017). TERRA also increases upon telomere damage due to TRF2 depletion and, in this setting, TERRA may sustain the telomeric DNA damage response (Porro et al. 2014b). In this view, the mode of function of TERRA is very different from telomeric DNA, which assem- bles similar amounts of shelterin components at all chromosome ends in a constitutive manner (Grolimund et al. 2013).

The large number of putative transcription factor binding sites in TERRA promoters may suggest different types of regulation at various chromosome ends. Our work identifies two classes of TERRA promoters in terms of regulation by DNA methyltransferases. Only CpG-island containing TERRA promoters become up-regulated upon loss of DNA methyltransferases, possibly suggesting separate functions of $\mathrm{CpG}$-island containing and lacking TERRA genes during early development, when DNA methylation is established. Impaired de novo methylation during embryogenesis leads to devastating effects in ICF1 patients who are characterized by short telomeres and high TERRA levels. Interestingly a recent study showed that loss of methylation in the subtelomeric CpG islands in HeLa led to an NRF1-dependent up-regulation of TERRA expression strengthening the link between CpG-island containing promoters and TERRA transcription (Le Berre et al. 2019). We established that the length of telomeres in DNA methyltransferase deficient DKO cells is shorter at chromosome ends independently of their individual TERRA expression levels. This suggests that either TERRA promotes telomere shortening also in trans at telomeres from which it is not up-regulated, or that the short telomere phenotype in DKO cells is not caused by TERRA overexpression. We failed to efficiently suppress TERRA expression at chromosome ends when targeted with transcriptional repressors via dCas9-constructs preventing us to further elucidate this question. 

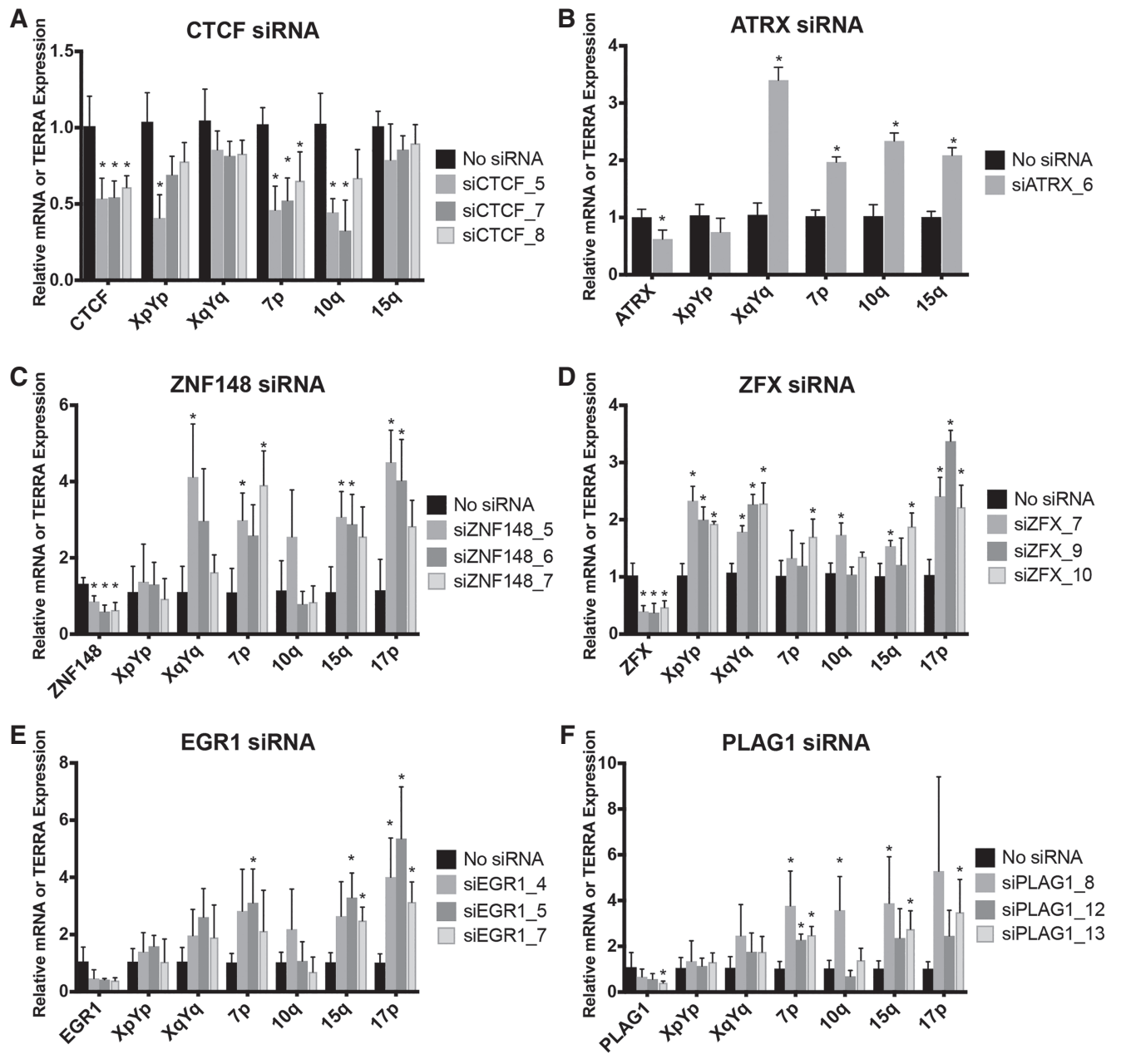

FIGURE 4. ZNF148 (C), ZFX (D), EGR1 (E), and PLAG1 (F) repress TERRA transcription. HeLa cells were transfected with siRNAs against transcription factors predicted to bind to subtelomeric DNA sequences. CTCF $(A)$ and ATRX $(B)$ depletion served as positive controls for a positive and negative regulator of TERRA transcription. $\left(^{*}\right) P<0.05, n=3$.

Our study cannot address if all telomeres or a large number of telomeres express TERRA, as some subtelomeric sequences are too repetitive to design chromosome end specific primer pairs. Furthermore, it is conceivable that TERRA transcription at some chromosome ends starts very close to the canonical 5'-TTAGGG-3' telomeric making the detection by chromosome end specific RT-PCR impossible. However, our data demonstrate unequivocally that TERRA is expressed from multiple chromosome ends in all analyzed human cell lines. Our analysis includes normal HLF, several telomerase-positive cancer cells, and the U2OS ALT-cell line. Blasco and coworkers concluded that TERRA stems in human cells predominantly from $20 \mathrm{q}$ based on work done mostly in the U2OS cells (Montero et al. 2016). For the following reasons we consider their conclusions as erroneous. First, Montero et al. (2016) claim that TERRA transcripts from other than 20q chromosome ends correspond to RNA derived from repetitive elements known as WASH and DDX11. Although we concur that some TERRA transcripts overlap with some subtelomeric gene families (Stong et al. 2014), we define TERRA transcripts as the ones whose transcription proceeds from subtelomeric DNA into terminal TTAGGGtracts (Azzalin et al. 2007). In contrast to TERRA, the subtelomeric WASH RNAs are not up-regulated in the DNA methyltransferase deficient DKO cells (Montero et al. 2016), as we document here for all TERRA genes that contain CpG-island promoters. Thus, CpG-island controlled TERRA genes do not share the promoters with WASH. Second, we demonstrate that 20q TERRA is not increased in the DKO cells as determined by relative and absolute quantification. Therefore, this TERRA is not responsible for the strong increase in TERRA levels in DKO cells, as predicted by Montero et al. (2016), who used DKO cells as a positive control in their northern blots. Third, Montero et al. isolated U2OS clones for which they claim that 9.5 $\mathrm{kb}$ encompassing the 20q TERRA promoter were deleted. In the northern blot analysis, the TERRA signal for one 
clone (C4) disappeared, but in the same lane, the crosshybridizing rRNA signal was also lost, revealing technical problems possibly with RNA intactness or detection. To conclude, our current quantitative analysis supports the conclusions from multiple laboratories that TERRA is expressed from a large number of chromosome ends. Our work is an important step forward toward studying TERRA as a large gene family that can be divided in terms of regulation into two broad classes based on the presence or absence of $\mathrm{CpG}$-island promoters.

\section{MATERIALS AND METHODS}

\section{Cell lines and culture conditions}

Telomerase positive cell line HeLa (cervical cancer) and ALT cell line U2OS (osteosarcoma) were acquired from ATCC. Telomerase positive human colon carcinoma cell lines HCT116 WT and DKO (DNMT1 $\Delta$ exons3-5/Aexons3-5 and DNMT3B ${ }^{-1-}$ ) were a kind gift from Bert Vogelstein (Ludwig Cancer Research, Johns Hopkins). The telomerase-negative normal human lung fibroblasts (HLF, passage 10-16) were described before (Ducrest et al. 2001). The cells were cultured in Dulbecco's modified Eagle's medium (Thermo Fisher Scientific) supplemented with 10\% fetal bovine serum (Thermo Fisher Scientific) and $100 \mathrm{U} / \mathrm{mL}$ of penicillin/ streptomycin (Thermo Fisher Scientific). The cells were maintained in $5 \% \mathrm{CO}_{2}$ incubator at $37^{\circ} \mathrm{C}$.

\section{siRNA-mediated RNA depletion}

The siRNAs were obtained from Qiagen in the form of a FlexiPlate. The sequences of the siRNAs used in this study are listed in Supplemental Table S3. Cells were transfected with 20 nM of siRNA using calcium phosphate transfection. The medium was changed $24 \mathrm{~h}$ after transfection and the cells were collected $48 \mathrm{~h}$ after transfection.

\section{RT-qPCR}

TERRA RT-qPCR was performed as previously described (Feretzaki and Lingner 2017). Briefly, RNA from 3 to 5 million cells was isolated using NucleoSpin RNA (Macherey-Nagel) and subjected to two on-column and one in-solution DNase digestions. Three micrograms of RNA was reverse-transcribed using $200 \mathrm{U}$ SuperScript III Reverse transcriptase (Thermo Fischer Scientific), GAPDH and TERRA reverse primers. Reverse transcription was performed at $55^{\circ} \mathrm{C}$ for $1 \mathrm{~h}$, followed by heat inactivation at $70^{\circ} \mathrm{C}$ for $15 \mathrm{~min}$. Ten percent of the reaction was mixed with $2 \times$ Power SYBR Green PCR Master mix (Applied Biosystems) and $0.5 \mu \mathrm{M}$ forward and reverse qPCR primers (see Supplemental Table S1 for sequences). qPCR consisted of $10 \mathrm{~min}$ at $95^{\circ} \mathrm{C}$ followed by 40 cycles at $95^{\circ} \mathrm{C}$ for $15 \mathrm{sec}$ and $60^{\circ} \mathrm{C}$ for $1 \mathrm{~min}$ in an Applied Biosystems 7900HT Fast Real-Time System. For comparison between two samples, averages and $P$-values were calculated using t-tests corrected for multiple comparisons using the Holm-Sidak method. For comparing multiple treatments, statisti- cal significance was calculated using two-way ANOVA followed by Tukey's multiple comparisons in Prism 8 software.

\section{TERRA absolute quantification}

To determine the copy number of TERRA by qPCR, we performed absolute quantification using a standard curve. The subtelomeric sequence of each TERRA species was amplified from HeLa and HCT116 using the Phusion Green High-Fidelity DNA polymerase and the primers listed in Supplemental Table S2. The PCR products were purified from a gel, cloned into the pCR4-Blunt-TOPO plasmid (Invitrogen) and verified by Sanger sequencing. The plasmids were quantified by a Qubit dsDNA High Sensitivity Assay Kit (Thermo Fischer Scientific) and used to create a standard curve using 2 to $2 \times 10^{8}$ molecules per reaction. qPCR was done as described above using the standard curve and sample cDNA. The number of copies of a specific TERRA species was calculated using the following formula:

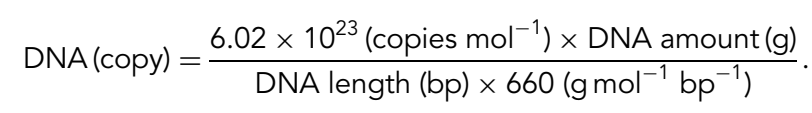

Each experiment was performed in duplicate. The $C_{t}$ values of each dilution were plotted against the logarithm of the respective template copy number and the curve was generated by linear regression. The percentage of the PCR amplification was calculated from the slope of each curve with the following formula:

$$
E=\left(10^{-1 / \text { slope }}-1\right) \times 100 .
$$

To calculate the copies of TERRA per cell, we determined a standard curve using in vitro transcribed TERRA. To generate the TERRA constructs for in vitro transcription, we cloned 400 to 500 bp of subtelomeric sequences of the $10 q, 15 q$, and $20 q$ subtelomeres upstream of 450 bp of telomeric repeats [(TTAGGG $)_{75}$ ]. A T7 promoter was used for in vitro transcription of TERRA (MAXIscript T7 Transcription Kit, AM1312, Thermo Fisher Scientific). The RNA products with the correct length were gel purified and measured with a Qubit RNA High Sensitivity Assay Kit (Thermo Fischer Scientific). RNA was diluted to create a standard curve and the qPCR was performed as described above. To calculate the number of TERRA copies per cell, we assumed that the RNA isolation was $100 \%$ efficient. The number of TERRA copies per cell was calculated using the formula described above.

\section{Single telomere length analysis (STELA)}

STELA was performed as previously described (Baird et al. 2003). Primers used are listed in Supplemental Table S4. Briefly, 3-5 $\mu \mathrm{g}$ of genomic DNA was digested with $100 \mathrm{U}$ of EcoRI (New England Biolabs) overnight at $37^{\circ} \mathrm{C}$. Digested DNA was purified with a GeneClean Turbo kit (MP Biomedicals). The DNA concentration was measured with the Qubit dsDNA High Sensitivity Assay Kit (Thermo Fischer Scientific). One hundred nanograms of DNA was mixed with $1 \mu \mathrm{M}$ telorette 3 and incubated at $60^{\circ} \mathrm{C}$ for 10 $\mathrm{min}$. The reaction was cooled down to room temperature before addition of $40 \mathrm{U}$ of T4 ligase (New England Biolabs) and $1 \mathrm{mM}$ ATP in a $10 \mu \mathrm{L}$ reaction. Ligations were incubated for $12 \mathrm{~h}$ at $35^{\circ} \mathrm{C}$ and then heat inactivated for $15 \mathrm{~min}$ at $70^{\circ} \mathrm{C}$. Two hundred to six hundred picograms of ligated DNA was used per PCR 
amplification. Reactions were done in $15 \mu \mathrm{L}$ containing $75 \mathrm{mM}$ Tris- $\mathrm{HCl}(\mathrm{pH} 8.8), 20 \mathrm{nM}(\mathrm{NH} 4)_{2} \mathrm{SO}_{4}, 0.01 \%$ Tween 20, $1.5 \mathrm{mM}$ $\mathrm{MgCl}_{2}, 0.5 \mu \mathrm{M}$ TelTail primer, $0.5 \mu \mathrm{M}$ forward primer, $0.3 \mathrm{mM}$ dNTPs, $1.5 \mathrm{U}$ of Taq Thermoprime Polymerase (ABgene), and $0.15 \mathrm{U}$ of Pwo polymerase (Roche). PCR conditions were the following: $94^{\circ} \mathrm{C}$ for $2 \mathrm{~min}$ (initial denaturation), 25 cycles of $94^{\circ} \mathrm{C}$ for $15 \mathrm{sec}, 65^{\circ} \mathrm{C}$ for $30 \mathrm{sec}, 68^{\circ} \mathrm{C}$ for $10 \mathrm{~min}$, followed by a 20 min final extension at $94^{\circ} \mathrm{C}$. PCRs were mixed with $3 \mu \mathrm{L}$ of $6 \times$ DNA loading buffer (New England Biolabs) and electrophoresed in a $0.8 \%$ agarose gel at $55 \mathrm{~V}$ for $15 \mathrm{~h}$. Gels were denatured in 0.5 $\mathrm{M} \mathrm{NaOH}$ and $1.5 \mathrm{M} \mathrm{NaCl}$, neutralized in $1.5 \mathrm{M} \mathrm{NaCl}$ and $0.5 \mathrm{M}$ Tris- $\mathrm{HCl} \mathrm{pH}$ 7.5. DNA was transferred by capillarity in $10 \times \mathrm{SSC}$ buffer onto a nylon membrane (Hybond $\mathrm{N}+$, GE Healthcare). DNA and membrane were UV-crosslinked and blocked in Church buffer (1\% BSA, 1 mM EDTA, 0.5 M phosphate buffer, $7 \%$ SDS). Membranes were incubated with ${ }^{32} \mathrm{P}$-radiolabeled telomeric probes overnight at $55^{\circ} \mathrm{C}$. Washes were done at $60^{\circ} \mathrm{C}$ with $2 \times \operatorname{SSC} 0.2 \%$ SDS $(2 \times 30 \mathrm{~min})$ and $0.2 \times \operatorname{SSC} 0.2 \%$ SDS $(2 \times 30$ $\mathrm{min})$. The molecular weight of each band was calculated using AIDA software (version 4.06.034). Averages and $P$-values ( $t$-tests corrected for multiple comparisons using the Holm-Sidak method) were calculated using the Prism 8 software.

\section{SUPPLEMENTAL MATERIAL}

Supplemental material is available for this article.

\section{ACKNOWLEDGMENTS}

We thank Claus Azzalin (Instituto de Medicina Molecular, Lisbon) for helping to set up the STELA protocol in our laboratory and Bert Vogelstein for HCT116 cell lines. M.F. was supported by a Marie Curie postdoctoral fellowship. P.R.N. was supported by a $\mathrm{PhD}$ fellowship from the Boehringer Ingelheim Fonds. Research in J.L.'s laboratory was supported by the Swiss National Science Foundation (SNSF), the SNSF funded NCCR RNA and disease network, an Initial Training Network (ITN) grant (aDDRess) from the European Commission's Seventh Framework Programme, and the Swiss Cancer League and EPFL.

Author contributions: M.F. and P.R.N. designed and validated primers for TERRA quantification by RT-qPCR. M.F. designed, performed, and analyzed the siRNA screen; cloned plasmids for in vitro TERRA transcription; and carried out RT-qPCR for absolute quantification of TERRA. P.R.N. performed the analysis of subtelomeric sequences, identification of $\mathrm{CpG}$ islands, and relative quantification of TERRA; cell culture and RNA isolation of all cell lines used for absolute quantification of TERRA; STELA experiments; preparation of figures. All authors contributed to writing the manuscript and design of experiments.

Received June 18, 2019; accepted July 25, 2019.

\section{REFERENCES}

Arnoult N, Van Beneden A, Decottignies A. 2012. Telomere length regulates TERRA levels through increased trimethylation of telomeric H3K9 and HP1 $\alpha$. Nat Struct Mol Biol 19: 948-956. doi:10 $.1038 /$ nsmb. 2364
Arora R, Lee Y, Wischnewski H, Brun CM, Schwarz T, Azzalin CM. 2014. RNaseH1 regulates TERRA-telomeric DNA hybrids and telomere maintenance in ALT tumour cells. Nat Commun 5: 5220. doi:10 .1038/ncomms6220

Aström AK, Voz ML, Kas K, Röijer E, Wedell B, Mandahl N, Van de Ven W, Mark J, Stenman G. 1999. Conserved mechanism of PLAG1 activation in salivary gland tumors with and without chromosome 8q12 abnormalities: identification of SII as a new fusion partner gene. Cancer Res 59: 918-923.

Azzalin CM, Lingner J. 2015. Telomere functions grounding on TERRA firma. Trends Cell Biol 25: 29-36. doi:10.1016/j.tcb.2014.08.007

Azzalin CM, Reichenbach P, Khoriauli L, Giulotto E, Lingner J. 2007. Telomeric repeat containing RNA and RNA surveillance factors at mammalian chromosome ends. Science 318: 798-801. doi:10 $.1126 /$ science. 1147182

Baird DM, Rowson J, Wynford-Thomas D, Kipling D. 2003. Extensive allelic variation and ultrashort telomeres in senescent human cells. Nat Genet 33: 203-207. doi:10.1038/ng1084

Balk B, Maicher A, Dees M, Klermund J, Luke-Glaser S, Bender K, Luke B. 2013. Telomeric RNA-DNA hybrids affect telomere-length dynamics and senescence. Nat Struct Mol Biol 20: 1199-1205. doi:10.1038/nsmb.2662

Cusanelli E, Romero CAP, Chartrand P. 2013. Telomeric noncoding RNA TERRA is induced by telomere shortening to nucleate telomerase molecules at short telomeres. Mol Cell 51: 780-791. doi:10.1016/j.molcel.2013.08.029

de Lange T. 2018. Shelterin-mediated telomere protection. Annu Rev Genet 52: 223-247. doi:10.1146/annurev-genet-032918-021921

Deng Z, Norseen J, Wiedmer A, Riethman H, Lieberman PM. 2009. TERRA RNA binding to TRF2 facilitates heterochromatin formation and ORC recruitment at telomeres. Mol Cell 35: 403-413. doi:10 .1016/j.molcel.2009.06.025

Deng Z, Wang Z, Stong N, Plasschaert R, Moczan A, Chen H-S, Hu S, Wikramasinghe P, Davuluri RV, Bartolomei MS, et al. 2012. A role for CTCF and cohesin in subtelomere chromatin organization, TERRA transcription, and telomere end protection. EMBO J 31: 4165-4178. doi:10.1038/emboj.2012.266

Diman A, Boros J, Poulain F, Rodriguez J, Purnelle M, Episkopou H, Bertrand L, Francaux M, Deldicque L, Decottignies A. 2016. Nuclear respiratory factor 1 and endurance exercise promote human telomere transcription. Sci Adv 2: e1600031. doi:10.1126/ sciadv. 1600031

Ducrest AL, Amacker M, Mathieu YD, Cuthbert AP, Trott DA, Newbold RF, Nabholz M, Lingner J. 2001. Regulation of human telomerase activity: repression by normal chromosome 3 abolishes nuclear telomerase reverse transcriptase transcripts but does not affect c-Myc activity. Cancer Res 61: 7594-7602.

Egger G, Jeong S, Escobar SG, Cortez CC, Li TWH, Saito Y, Yoo CB, Jones PA, Liang G. 2006. Identification of DNMT1 (DNA methyltransferase 1) hypomorphs in somatic knockouts suggests an essential role for DNMT1 in cell survival. Proc Natl Acad Sci 103: 14080-14085. doi:10.1073/pnas.0604602103

Eid R, Demattei M-V, Episkopou H, Augé-Gouillou C, Decottignies A, Grandin N, Charbonneau M. 2015. Genetic inactivation of ATRX leads to a decrease in the amount of telomeric cohesin and level of telomere transcription in human glioma cells. Mol Cell Biol 35: 2818-2830. doi:10.1128/MCB.01317-14

Episkopou H, Draskovic I, Van Beneden A, Tilman G, Mattiussi M, Gobin M, Arnoult N, Londoño-Vallejo A, Decottignies A. 2014. Alternative lengthening of telomeres is characterized by reduced compaction of telomeric chromatin. Nucleic Acids Res 42: 43914405. doi:10.1093/nar/gku114

Farnung BO, Brun CM, Arora R, Lorenzi LE, Azzalin CM. 2012. Telomerase efficiently elongates highly transcribing telomeres in 
human cancer cells. PLoS One 7: e35714. doi:10.1371/journal .pone.0035714

Feretzaki M, Lingner J. 2017. A practical qPCR approach to detect TERRA, the elusive telomeric repeat-containing RNA. Methods 114: 39-45. doi:10.1016/j.ymeth.2016.08.004

Flynn RL, Cox KE, Jeitany M, Wakimoto H, Bryll AR, Ganem NJ, Bersani F, Pineda JR, Suvà ML, Benes CH, et al. 2015. Alternative lengthening of telomeres renders cancer cells hypersensitive to ATR inhibitors. Science 347: 273-277. doi:10.1126/sci ence. 1257216

Frattini A, Fabbri M, Valli R, De Paoli E, Montalbano G, Gribaldo L, Pasquali F, Maserati E. 2015. High variability of genomic instability and gene expression profiling in different HeLa clones. Sci Rep 5: 15377. doi:10.1038/srep15377

Galan-Caridad JM, Harel S, Arenzana TL, Hou ZE, Doetsch FK, Mirny LA, Reizis B. 2007. Zfx controls the self-renewal of embryonic and hematopoietic stem cells. Cell 129: 345-357. doi:10.1016/j .cell.2007.03.014

Graf M, Bonetti D, Lockhart A, Serhal K, Kellner V, Maicher A, Jolivet P, Teixeira MT, Luke B. 2017. Telomere length determines TERRA and R-loop regulation through the cell cycle. Cell 170: 72-85. e145. doi:10.1016/j.cell.2017.06.006

Grolimund L, Aeby E, Hamelin R, Armand F, Chiappe D, Moniatte M, Lingner J. 2013. A quantitative telomeric chromatin isolation protocol identifies different telomeric states. Nat Commun 4: 2848. doi:10.1038/ncomms3848

Harel S, Tu EY, Weisberg S, Esquilin M, Chambers SM, Liu B, Carson CT, Studer L, Reizis B, Tomishima MJ. 2012. ZFX controls the self-renewal of human embryonic stem cells. PLoS One 7: e42302. doi:10.1371/journal.pone.0042302

Hirschi A, Martin WJ, Luka Z, Loukachevitch LV, Reiter NJ. 2016. Gquadruplex RNA binding and recognition by the lysine-specific histone demethylase-1 enzyme. RNA 22: 1250-1260. doi:10 .1261/rna.057265.116

Janssen A, Medema RH. 2013. Genetic instability: tipping the balance. Oncogene 32: 4459-4470. doi:10.1038/onc.2012.576

Knutsen T, Padilla-Nash HM, Wangsa D, Barenboim-Stapleton L, Camps J, McNeil N, Difilippantonio MJ, Ried T. 2010. Definitive molecular cytogenetic characterization of 15 colorectal cancer cell lines. Genes Chromosomes Cancer 49: 204-223. doi:10 .1002/gcc.20730

Koskas S, Decottignies A, Dufour S, Pezet M, Verdel A, Vourc'h C, Faure V. 2017. Heat shock factor 1 promotes TERRA transcription and telomere protection upon heat stress. Nucleic Acids Res 45: 6321-6333. doi:10.1093/nar/gkx208

Landry JJM, Pyl PT, Rausch T, Zichner T, Tekkedil MM, Stütz AM, Jauch A, Aiyar RS, Pau G, Delhomme N, et al. 2013. The genomic and transcriptomic landscape of a HeLa cell line. G3(Bethesda) 3: 1213-1224. doi:10.1534/g3.113.005777

Lazzerini-Denchi E, Sfeir A. 2016. Stop pulling my strings-what telomeres taught us about the DNA damage response. Nat Rev Mol Cell Biol 17: 364-378. doi:10.1038/nrm.2016.43

Le Berre G, Hossard V, Riou J-F, Guieysse-Peugeot A-L. 2019. Repression of TERRA expression by subtelomeric DNA methylation is dependent on NRF1 binding. Int J Mol Sci 20: 2791. doi:10.3390/ijms20112791

Liu B, Maekawa T, Yoshida K, Ly NH, Inoue K, Hasegawa A, Chatton B, Ogura A, Ishii S. 2019. Telomere shortening by transgenerational transmission of TNF- $\alpha$-induced TERRA via ATF7. Nucleic Acids Res 47: 283-298. doi:10.1093/nar/gky1149

López de Silanes I, Graña O, De Bonis ML, Dominguez O, Pisano DG, Blasco MA. 2014. Identification of TERRA locus unveils a telomere protection role through association to nearly all chromosomes. Nat Commun 5: 4723. doi:10.1038/ncomms5723
Lovejoy CA, Li W, Reisenweber S, Thongthip S, Bruno J, de Lange T, De S, Petrini JHJ, Sung PA, Jasin M, et al. 2012. Loss of ATRX, genome instability, and an altered DNA damage response are hallmarks of the alternative lengthening of telomeres pathway. PLoS Genet 8: e1002772. doi:10.1371/journal.pgen.1002772

Mazzolini R, Gonzàlez N, Garcia-Garijo A, Millanes-Romero A, Peiró S, Smith S, García de Herreros A, Canudas S. 2018. Snail1 transcription factor controls telomere transcription and integrity. Nucleic Acids Res 46: 146-158. doi:10.1093/nar/gkx958

Miller KM, Rog O, Cooper JP. 2006. Semi-conservative DNA replication through telomeres requires Taz1. Nature 440: 824-828. doi:10.1038/nature04638

Montero JJ, López de Silanes I, Graña O, Blasco MA. 2016. Telomeric RNAs are essential to maintain telomeres. Nat Commun 7: 12534. doi:10.1038/ncomms12534

Moravec M, Wischnewski H, Bah A, Hu Y, Liu N, Lafranchi L, King MC, Azzalin CM. 2016. TERRA promotes telomerase-mediated telomere elongation in Schizosaccharomyces pombe. EMBO Rep 17: 999-1012. doi:10.15252/embr.201541708

Nergadze SG, Farnung BO, Wischnewski H, Khoriauli L, Vitelli V, Chawla R, Giulotto E, Azzalin CM. 2009. CpG-island promoters drive transcription of human telomeres. RNA 15: 2186-2194. doi:10.1261/rna.1748309

Ozaki T, Neumann T, Wai D, Schäfer K-L, van Valen F, Lindner $N$, Scheel C, Böcker W, Winkelmann W, Dockhorn-Dworniczak B, et al. 2003. Chromosomal alterations in osteosarcoma cell lines revealed by comparative genomic hybridization and multicolor karyotyping. Cancer Genet Cytogenet 140: 145-152. doi:10.1016/ S0165-4608(02)00685-4

Park Y-J, Kim EK, Bae JY, Moon S, Kim J. 2016. Human telomerase reverse transcriptase (hTERT) promotes cancer invasion by modulating cathepsin D via early growth response (EGR)-1. Cancer Lett 370: 222-231. doi:10.1016/j.canlet.2015.10.021

Passantino R, Antona V, Barbieri G, Rubino P, Melchionna R, Cossu G, Feo $S$, Giallongo A. 1998. Negative regulation of $\beta$ enolase gene transcription in embryonic muscle is dependent upon a zinc finger factor that binds to the G-rich box within the muscle-specific enhancer. J Biol Chem 273: 484-494. doi:10.1074/jbc.273.1.484

Passerini V, Ozeri-Galai E, de Pagter MS, Donnelly N, Schmalbrock S, Kloosterman WP, Kerem B, Storchová Z. 2016. The presence of extra chromosomes leads to genomic instability. Nat Commun 7: 10754. doi:10.1038/ncomms 10754

Pfeiffer V, Lingner J. 2012. TERRA promotes telomere shortening through exonuclease 1-mediated resection of chromosome ends. PLoS Genet 8: e1002747. doi:10.1371/journal.pgen 1002747

Pickett HA, Reddel RR. 2015. Molecular mechanisms of activity and derepression of alternative lengthening of telomeres. Nat Struct Mol Biol 22: 875-880. doi:10.1038/nsmb.3106

Porro A, Feuerhahn S, Reichenbach P, Lingner J. 2010. Molecular dissection of telomeric repeat-containing RNA biogenesis unveils the presence of distinct and multiple regulatory pathways. Mol Cell Biol 30: 4808-4817. doi:10.1128/MCB.00460-10

Porro A, Feuerhahn S, Delafontaine J, Riethman H, Rougemont J, Lingner J. 2014a. Functional characterization of the TERRA transcriptome at damaged telomeres. Nat Commun 5: 5379. doi:10 .1038/ncomms6379

Porro A, Feuerhahn S, Lingner J. 2014b. TERRA-reinforced association of LSD1 with MRE11 promotes processing of uncapped telomeres. Cell Rep 6: 765-776. doi:10.1016/j.celrep.2014.01.022

Redon S, Reichenbach P, Lingner J. 2010. The non-coding RNA TERRA is a natural ligand and direct inhibitor of human telomerase. Nucleic Acids Res 38: 5797-5806. doi:10.1093/nar/gkq296

Rhee I, Bachman KE, Park BH, Jair K-W, Yen R-WC, Schuebel KE, Cui H, Feinberg AP, Lengauer C, Kinzler KW, et al. 2002. 
DNMT1 and DNMT3b cooperate to silence genes in human cancer cells. Nature 416: 552-556. doi:10.1038/416552a

Sagie S, Toubiana S, Hartono SR, Katzir H, Tzur-Gilat A, Havazelet S, Francastel C, Velasco G, Chédin F, Selig S. 2017. Telomeres in ICF syndrome cells are vulnerable to DNA damage due to elevated DNA:RNA hybrids. Nat Commun 8: 14015. doi:10.1038/ ncomms 14015

Schmidt JC, Cech TR. 2015. Human telomerase: biogenesis, trafficking, recruitment, and activation. Genes Dev 29: 1095-1105. doi:10.1101/gad.263863.115

Schoeftner S, Blasco MA. 2008. Developmentally regulated transcription of mammalian telomeres by DNA-dependent RNA polymerase II. Nat Cell Biol 10: 228-236. doi:10.1038/ncb1685

Sfeir A, Kosiyatrakul ST, Hockemeyer D, MacRae SL, Karlseder J, Schildkraut CL, de Lange T. 2009. Mammalian telomeres resemble fragile sites and require TRF1 for efficient replication. Cell 138: 90103. doi:10.1016/j.cell.2009.06.021

Stong N, Deng Z, Gupta R, Hu S, Paul S, Weiner AK, Eichler EE, Graves T, Fronick CC, Courtney L, et al. 2014. Subtelomeric CTCF and cohesin binding site organization using improved subtelomere assemblies and a novel annotation pipeline. Genome Res 24: 1039-1050. doi:10.1101/gr.166983.113
Tardat M, Déjardin J. 2018. Telomere chromatin establishment and its maintenance during mammalian development. Chromosoma 127: 3-18. doi:10.1007/s00412-017-0656-3

Tutton S, Azzam GA, Stong N, Vladimirova O, Wiedmer A, Monteith JA, Beishline K, Wang Z, Deng Z, Riethman H, et al. 2016. Subtelomeric p53 binding prevents accumulation of DNA damage at human telomeres. EMBO J 35: 193-207. doi:10 .15252/embj.201490880

Wang X, Goodrich KJ, Gooding AR, Naeem H, Archer S, Paucek RD, Youmans DT, Cech TR, Davidovich C. 2017. Targeting of polycomb repressive complex 2 to RNA by short repeats of consecutive guanines. Mol Cell 65: 1056-1067.e5. doi:10.1016/j.molcel .2017 .02 .003

Yehezkel S, Segev Y, Viegas-Péquignot E, Skorecki K, Selig S. 2008. Hypomethylation of subtelomeric regions in ICF syndrome is associated with abnormally short telomeres and enhanced transcription from telomeric regions. Hum Mol Genet 17: 2776-2789. doi:10.1093/hmg/ddn177

Zatkova A, Rouillard J-M, Hartmann W, Lamb BJ, Kuick R, Eckart M, von Schweinitz D, Koch A, Fonatsch C, Pietsch T, et al. 2004. Amplification and overexpression of the IGF2 regulator PLAG1 in hepatoblastoma. Genes Chromosomes Cancer 39: 126-137. doi:10.1002/gcc.10307 

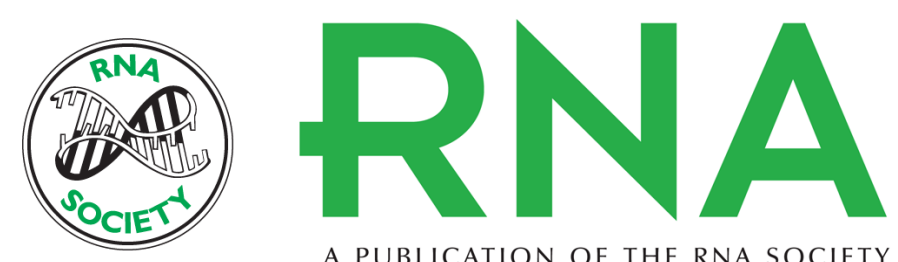

A PUBLICATION OF THE RNA SOCIETY

\section{Expression and differential regulation of human TERRA at several chromosome ends}

Marianna Feretzaki, Patricia Renck Nunes and Joachim Lingner

RNA 2019 25: 1470-1480 originally published online July 26, 2019

Access the most recent version at doi:10.1261/rna.072322.119

\section{Supplemental http://rnajournal.cshlp.org/content/suppl/2019/07/26/rna.072322.119.DC1 Material}

References This article cites 60 articles, 15 of which can be accessed free at: http://rnajournal.cshlp.org/content/25/11/1470.full.html\#ref-list-1

Creative This article is distributed exclusively by the RNA Society for the first 12 months after the Commons License full-issue publication date (see http://rnajournal.cshlp.org/site/misc/terms.xhtml). After 12 months, it is available under a Creative Commons License (Attribution-NonCommercial 4.0 International), as described at http://creativecommons.org/licenses/by-nc/4.0/.

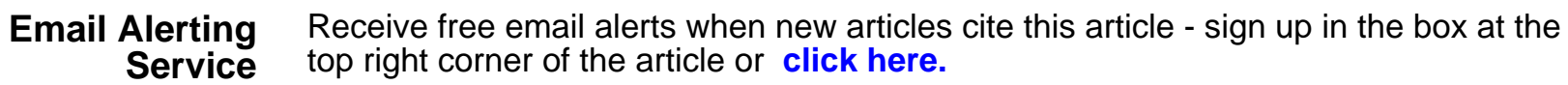

